\title{
Neurosteroid biosynthesis in the brain of amphibians
}

\author{
Hubert Vaudry 1 *, Jean-Luc Do Rego ${ }^{1}$, Delphine Burel ${ }^{1}$, Van Luu-The ${ }^{2}$, Georges Pelletier ${ }^{2}$, David Vaudry ${ }^{1}$ and \\ Kazuyoshi Tsutsui ${ }^{3}$ \\ Laboratory of Neuronal and Neuroendocrine Differentiation and Communication, INSERM U982, European Institute for Peptide Research, IFRMP23, Regional \\ Platform for Cell Imaging, PRIMACEN, University of Rouen, Mont-Saint-Aignan, France \\ 2 Research Center in Molecular Endocrinology, Oncology and Genetics, Laval University Hospital Center, Québec, QC, Canada \\ ${ }^{3}$ Laboratory of Integrative Brain Science, Department of Biology, Center for Medical Life Science of Waseda University, Waseda University, Tokyo, Japan
}

\section{Edited by:}

Eric W. Roubos, Radboud University Nijmegen, Netherlands

\section{Reviewed by:}

Maria M. Malagon, University of

Cordoba, Spain

Mauro Vallarino, University of Genova, Italy

María Jesús Delgado, Complutense

University of Madrid, St. Helena

*Correspondence:

Hubert Vaudry, Laboratory of Neuronal and Neuroendocrine

Differentiation and Communication (INSERM U982), European Institute for Peptide Research (IFRMP23), International Associated Laboratory

Samuel de Champlain, Regional

Platform for Cell Imaging

(PRIMACEN), University of Rouen,

76821 Mont-Saint-Aignan, France.

e-mail: hubert.vaudry@univ-rouen.fr
Amphibians have been widely used to investigate the synthesis of biologically active steroids in the brain and the regulation of neurosteroid production by neurotransmitters and neuropeptides. The aim of the present review is to summarize the current knowledge regarding the neuroanatomical distribution and biochemical activity of steroidogenic enzymes in the brain of anurans and urodeles. The data accumulated over the past two decades demonstrate that discrete populations of neurons and/or glial cells in the frog and newt brains express the major steroidogenic enzymes and are able to synthesize de novo a number of neurosteroids from cholesterol/pregnenolone. Since neurosteroidogenesis has been conserved during evolution from amphibians to mammals, it appears that neurosteroids must play important physiological functions in the central nervous system of vertebrates.

Keywords: neurosteroids, amphibians, steroidogenic enzymes, brain

\section{INTRODUCTION}

Steroid hormones play a crucial role in the development, growth, and differentiation of the central nervous system (CNS; McEwen, 1992; Compagnone and Mellon, 2000; Sakamoto et al., 2001; Karishma and Herbert, 2002; Wang et al., 2005; Lazaridis et al., 2011). Because of their lipophilic nature, circulating steroids can readily cross the blood-brain barrier, and it has long been assumed that the adrenal gland, gonads, and placenta were the sole sources of steroid hormones acting on the brain. However, in the early 1980s, Baulieu, Robel, and co-workers made a series of seminal observations which revealed that this view was not correct. They initially found that the concentrations of several steroids, including pregnenolone $\left(\Delta^{5} \mathrm{P}\right)$, dehydroepiandrosterone (DHEA), and their sulfate esters, were much higher in the central and peripheral nervous systems than in the plasma (Corpéchot et al., 1981, 1983). They then reported that the level of certain brain steroids remained elevated after adrenalectomy and castration, and that ACTH treatment, although increasing plasma $\Delta^{5} \mathrm{P}$ level, did not affect $\Delta^{5} \mathrm{P}$ concentration in brain tissue (Corpéchot et al., 1981, 1983; Robel and Baulieu, 1985; Cheney et al., 1995). These observations led them to hypothesize that the brain had the capability of synthesizing de novo biologically active steroids. In support of this hypothesis, the presence of steroidogenic enzymes has now been visualized by immunohistochemistry and in situ hybridization, either in neurons or in glial cells, in the brain of various representative vertebrate species, and the occurrence of the corresponding enzymatic activities has been ascertained through biochemical approaches (Mensah-Nyagan et al., 1999; Tsutsui et al., 1999; Compagnone and Mellon, 2000; Mellon and Vaudry, 2001; Do Rego et al., 2009).

Concurrently, it has been shown that brain-born steroids (now called neurosteroids) exert pleiotropic activities in the CNS. Neurosteroids act either via conventional nuclear receptors or via allosteric modulation of membrane receptors, e.g., $\mathrm{GABA}_{\mathrm{A}}$, glycine, NMDA, kainate, AMPA, sigma, nicotinic, muscarinic, and serotonergic receptors (Majewska, 1992; Belelli and Lambert, 2005; Belelli et al., 2006; Herd et al., 2007).

The amphibian brain is a very convenient model to study neurosteroidogenesis. Firstly, most enzymes of the steroidogenic pathways are expressed in the CNS of amphibians. Secondly, the activity of the steroidogenic enzymes in the brain of amphibians is very high, thus making it possible to investigate the effects of inhibitory factors regulating neurosteroidogenesis. Thirdly, because of its relatively small size, the brain of amphibians is particularly suitable for studying the neuroanatomical distribution of neurosteroidproducing cells. The present report summarizes the current knowledge concerning the occurrence, distribution, and biological activity of steroidogenic enzymes in the brain of amphibians. A companion paper describes the neuronal mechanisms involved in the regulation of neurosteroidogenesis in amphibians (Do Rego et al., submitted). 


\section{TRANSLOCATOR PROTEIN}

Translocator protein (TSPO) is an $18-\mathrm{kDa}$ protein that is part of the peripheral benzodiazepine receptor complex (Papadopoulos et al., 2006). TSPO, which is primarily located on the outer mitochondrial membrane, binds with high affinity cholesterol and enhances its translocation to the inner mitochondrial membrane (Papadopoulos et al., 1997; Rupprecht et al., 2009). In the brain of the European green frog Rana esculenta, the distribution of TSPO has been determined by immunohistochemistry using polyclonal antibodies against a synthetic fragment of the human protein (Oke et al., 1992). TSPO-immunoreactive cells are located in several nuclei of the telencephalon and diencephalon including the anterior commissure, the lateral and medial pallium, the lateral septum, the medial amygdala, the anterior preoptic area, the dorsal hypothalamic nucleus, the posterior tuberculum, the suprachiasmatic nucleus, and the ventral habenular nucleus (Do Rego et al., 1998). Interestingly, in several of these nuclei, TSPO is co-localized with the steroidogenic enzyme $3 \beta$-hydroxysteroid dehydrogenase ( $3 \beta$ HSD) supporting the involvement of TSPO in the biosynthesis of neurosteroids in the frog brain (Do Rego et al., 1998).

\section{STEROID ACUTE REGULATORY PROTEIN}

Steroid acute regulatory protein (StAR) is a $30-\mathrm{kDa}$ protein that plays a major role in the transfer of cholesterol from the outer to the inner membrane of mitochondria (Stocco, 2001). StAR mRNA is actively expressed in the brain of mammals including human
(Furukawa et al., 1998; Inoue et al., 2002). In the human frontal cortex, immunohistochemical studies have shown that StAR and cytochrome $\mathrm{P} 450$ side-chain cleavage (P450scc) co-exist in a discrete population of neurons. The expression of the StAR gene has also been evidenced in the brain of birds (London et al., 2006) and fish (Nunez et al., 2005; Lyssimachou and Arukwe, 2007; Arukwe, 2008; Kusakabe et al., 2009). However, up to now, the occurrence of StAR has not yet been investigated in the frog brain (Do Rego et al., 2009).

\section{CYTOCHROME P450 SIDE-CHAIN CLEAVAGE}

Cytochrome P450 scc $(C Y P 11 A 1)$, a member of the cytochrome P450 superfamily of enzymes, is located on the inner mitochondrial membrane (Farkash et al., 1986). P450 scc $_{\text {is }}$ a rate-limiting and hormonally regulated enzyme that catalyzes the conversion of cholesterol into $\Delta^{5} \mathrm{P}$, the universal precursor of all steroid hormones (Guo et al., 2007; Lavoie and King, 2009; Figure 1). P450 $\mathrm{scc}$ was the first steroidogenic enzyme whose presence was detected in the CNS (Le Goascogne et al., 1987). Since then, the occurrence of $\mathrm{P}^{4} 50_{\mathrm{scc}}$ has been reported in the brain of rodents (Compagnone et al., 1995a; Ukena et al., 1998; Kimoto et al., 2001) and primates (Le Goascogne et al., 1989) as well as in birds (Tsutsui and Yamazaki, 1995; Usui et al., 1995; Lea et al., 2001; London et al., 2006). In amphibians, the localization of $\mathrm{P} 450_{\text {scc }}$ has been described in both anurans and urodeles. In the clawed toad Xenopus laevis and the frog Rana nigromaculata, $\mathrm{P} 450_{\text {scc }}$ is particularly

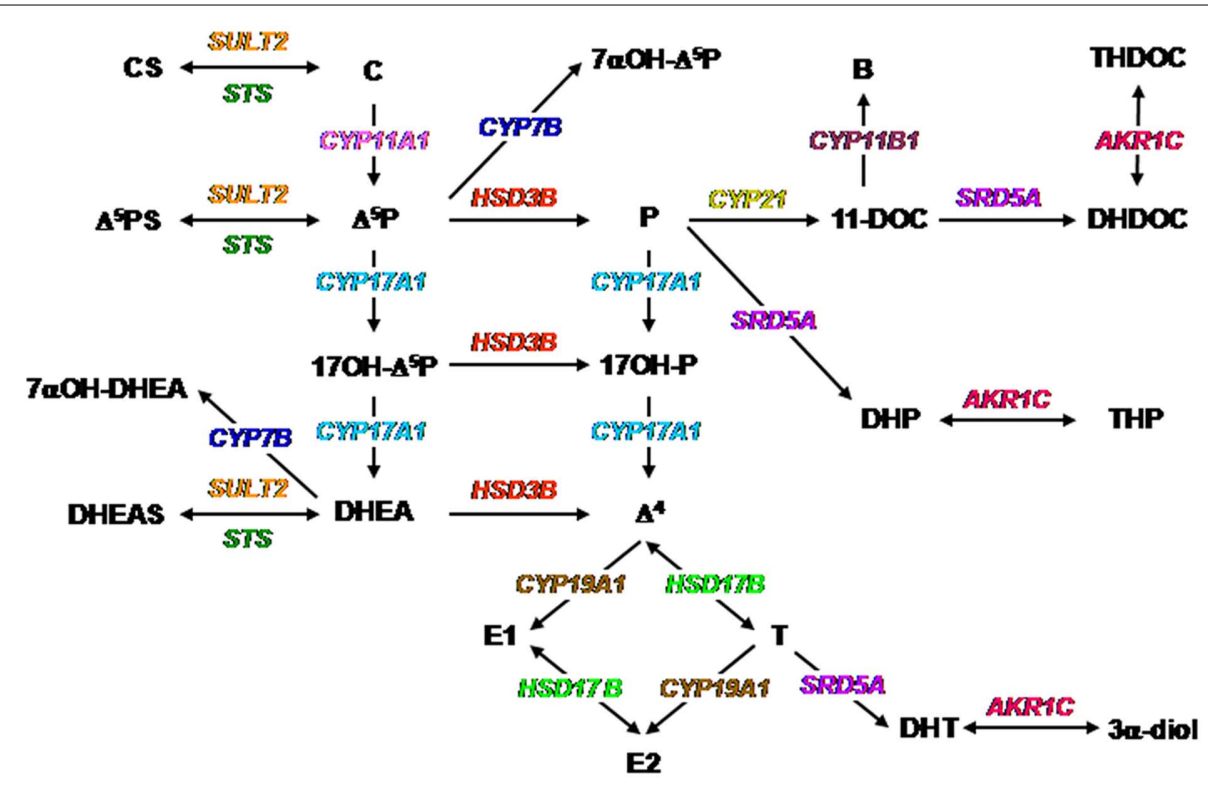

FIGURE 1 | Biochemical pathways for the synthesis of neurosteroids. The color code is the same as that used in Figures 2-6. Abbreviations for steroids: $B$, corticosterone; $C$, cholesterol; $C S$, cholesterol sulfate; $\Delta^{4}$,

androstenedione; $\Delta^{5}$ P, pregnenolone; $\Delta^{5} \mathrm{PS}$, pregnenolone sulfate; DHEA, dehydroepiandrosterone; DHEAS, dehydroepiandrosterone sulfate; DHDOC, dihydrodeoxycorticosterone; DHP, dihydroprogesterone; DHT, dihydrotestosterone; E1, estrone; E2, estradiol; P, progesterone; T, testosterone; THDOC, tetrahydrodeoxycorticosterone; THP, tetrahydroprogesterone; $3 \alpha$-diol, androstanediol; $7 \alpha-\mathrm{OH}-\Delta^{5} \mathrm{P}$, $7 \alpha$-hydroxypregnenolone; $7 \alpha-\mathrm{OH}$-DHEA, $7 \alpha$-hydroxydehydroepiandrosterone;
11-DOC, 11-deoxycorticosterone; $170 \mathrm{H}-\Delta^{5} \mathrm{P}$, 17-hydroxypregnenolone; $170 \mathrm{H}-\mathrm{P}$ 17-hydroxyprogesterone. Abbreviations for enzymes: AKR1C, $3 \alpha$-hydroxysteroid dehydrogenase; CYP7A1, oxysterol $7 \alpha$-hydroxylase (cytochrome $\mathrm{P} 450_{7 \alpha}$ ); CYP11A1, cytochrome P450 side-chain cleavage; CYP11B1, 11 $\beta$-hydroxylase (cytochrome P450 ${ }_{\text {C11 }}$ ); CYP17A1, cytochrome P450 17 $\alpha$-hydroxylase/C17, 20-lyase; CYP19A1, cytochrome P450 aromatase;

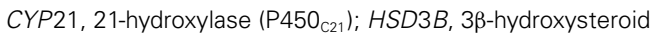
dehydrogenase $/ \Delta^{5}-\Delta^{4}$ isomerase; $H S D 17 B, 17 \beta$-hydroxysteroid dehydrogenase; SRD5A, $5 \alpha$-reductase; STS, sulfatase; SULT2, hydroxysteroid sulfotransferase. 
abundant in the ventral hypothalamic nucleus and the medial pal-

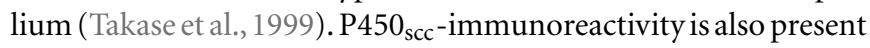
in the anterior preoptic area, the dorsal and lateral pallium, the dorsal striatum, the ventral part of the magnocellular preoptic nucleus, the optic tectum, the pretectal gray, Purkinje cells in the cerebellum, and lamina six (Takase et al., 1999). In R. esculenta, $\mathrm{P} 450_{\text {scc }}$-immunoreactivity is found in both neurons and glial cells (unpublished observations). The fact that the concentrations of $\Delta^{5} \mathrm{P}$ in the brain of X. laevis (Takase et al., 1999), R. esculenta (Mensah-Nyagan et al., 1994), and the red-bellied newt Cynops pyrrhogaster (Inai et al., 2003) are higher than in the plasma and even the gonads suggests that the $\mathrm{P} 450_{\mathrm{scc}}$-immunoreactive protein detected in the brain of these amphibian species actually corresponds to a biologically active form of the enzyme. In support of this hypothesis, a recent study has shown the conversion of cholesterol into $\Delta^{5} \mathrm{P}$ in the newt brain (Takase et al., 2011).

\section{3 $\beta$-HYDROXYSTEROID DEHYDROGENASE}

$3 \beta$-Hydroxysteroid dehydrogenase $/ \Delta^{4}-\Delta^{5}$ isomerase $(3 \beta-H S D$; $H S D 3 B)$ is a membrane bound enzyme that catalyzes the conversion of $\Delta^{5}$-3 $\beta$-hydroxysteroids into $\Delta^{4}$-3-ketosteroids (Figure 1). This enzyme is thus essential for the biosynthesis of all classes of steroid hormones including progesterone $(\mathrm{P})$, glucocorticoids, mineralocorticoids, androgens, and estrogens (Payne and Hales, 2004; Simard et al., 2005). The existence of $3 \beta$-HSD mRNA and/or protein has been documented in the brain of mammals (Dupont et al., 1994; Guennoun et al., 1995; Sanne and Krueger, 1995; Ukena et al., 1999a) and birds (Ukena et al., 1999b, 2001). In amphibians, the neuroanatomical distribution of $3 \beta$-HSD immunoreactivity has been described in the CNS of $R$. esculenta (Mensah-Nyagan et al., 1994) and C. pyrrhogaster (Inai et al., 2003). In adult frog, $3 \beta$-HSD-containing neurons are exclusively located in the diencephalon, namely in the anterior preoptic area and the dorsal and ventral hypothalamic nuclei (Figure 2). These neurons send projections in the telencephalon, notably in the nucleus accumbens, and in various nuclei of the diencephalon (Mensah-Nyagan et al., 1994). During early development (stages IV-XII), intense $3 \beta$-HSD immunoreactivity is found in the dorsal part of the anterior olfactory nucleus (Bruzzone et al., 2010). The concentration of $\mathrm{P}$ in the frog hypothalamus is about 200-fold higher than in the plasma (Mensah-Nyagan et al., 1994). Likewise, in the brain of the toad X. laevis and the newt C. pyrrhogaster, $\mathrm{P}$ levels are higher than in the plasma and gonads (Takase et al., 1999; Inai et al., 2003) suggesting that brain P does not originate from steroidogenic glands. Consistent with this notion, incubation of frog hypothalamic explants or newt brain homogenates with tritiated pregnenolone $\left(\left[{ }^{3} \mathrm{H}\right] \Delta^{5} \mathrm{P}\right)$ yields to the formation of various newly synthesized steroids including $\left[{ }^{3} \mathrm{H}\right] \mathrm{P}$ (Mensah-Nyagan et al., 1994; Inai et al., 2003). Taken together, these observations indicate that $3 \beta$-HSD immunoreactivity detected in the brain of amphibians is biologically active.

\section{CYTOCHROME P450 $7 \alpha$}

Cytochrome $\mathrm{P} 450_{7 \alpha}\left(\mathrm{P}_{450} 0_{7 \alpha} ; C Y P 7 A 1\right)$ is a microsomal enzyme with broad substrate specificity for sterol metabolites (Gilardi et al., 2007; Norlin and Wikvall, 2007; Figure 1). One of the

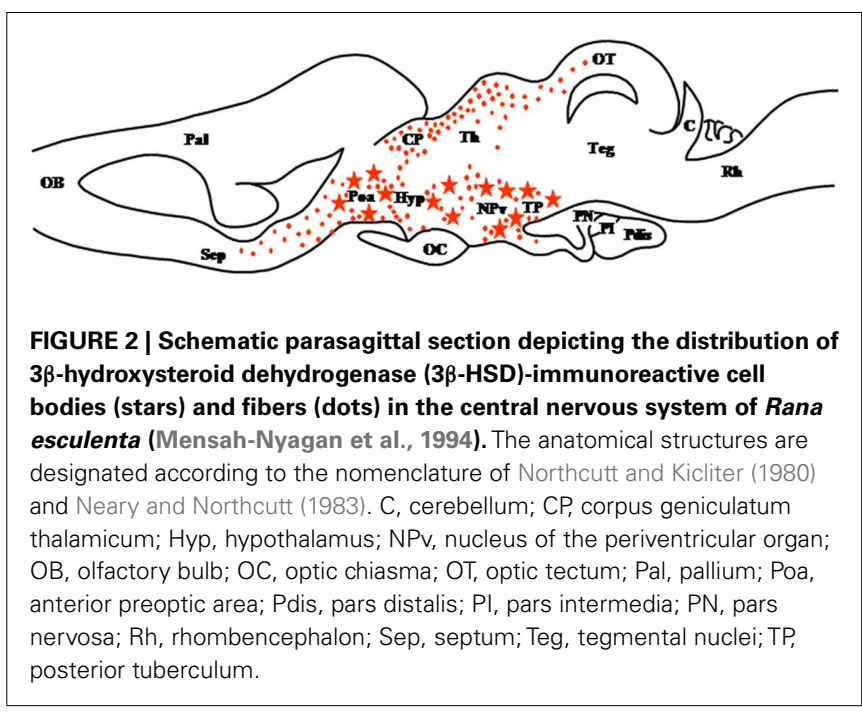

isoforms of $\mathrm{P} 450_{7 \alpha}, C Y P 7 B$, is expressed in the brain of mammals (Stapleton et al., 1995) and birds (Tsutsui et al., 2008). The first evidence for the presence of $\mathrm{P}^{4} 50_{7 \alpha}$ in the brain of amphibians was provided by Matsunaga et al. (2004) who showed that the brain of the newt $C$. pyrrhogaster actively converts $\left[{ }^{3} \mathrm{H}\right] \Delta \Delta^{5} \mathrm{P}$ into tritiated $7 \alpha$-hydroxypregnenolone $\left(\left[{ }^{3} \mathrm{H}\right] 7 \alpha-\mathrm{OH}-\right.$ $\left.\triangle^{5} \mathrm{P}\right)$. Subsequently, $C Y P 7 B$ was cloned from the newt brain confirming the occurrence of $\mathrm{P}^{4} 50_{7 \alpha}$ in the CNS of amphibians (Haraguchi et al., 2010). Newt CYP7B-transfected COS-7 cells can catalyze the conversion of $\left[{ }^{3} \mathrm{H}\right] \Delta^{5} \mathrm{P}$ into $\left[{ }^{3} \mathrm{H}\right] 7 \alpha-\mathrm{OH}-\Delta^{5} \mathrm{P}$, and the enzymatic activity is blocked by the cytochrome $\mathrm{P} 450$ inhibitor ketoconazole (Haraguchi et al., 2010). In the newt brain, CYP7B-immunoreactive cells are primarily located in the anterior preoptic area, the magnocellular preoptic nucleus, and the tegmental area. Immunoreactive cells are also found in the lateral and dorsal pallium, the suprachiasmatic nucleus, the ventral hypothalamic nucleus, and the tectum mesencephali (Haraguchi et al., 2010). Recent studies have shown that the synthesis of $7 \alpha-\mathrm{OH}-\Delta^{5} \mathrm{P}$ in the newt brain undergoes marked diurnal and seasonal variations in parallel with changes in locomotor activity (Matsunaga et al., 2004; Tsutsui et al., 2008, 2010a,b; Haraguchi et al., 2009; Koyama et al., 2009). The observation that $7 \alpha-\mathrm{OH}-\Delta^{5} \mathrm{P}$ biosynthesis in the newt brain is stimulated by melatonin (Tsutsui et al., 2010a) and prolactin (Haraguchi et al., 2010) strongly suggests that these two factors are responsible, respectively, for the diurnal and seasonal variations in $7 \alpha-\mathrm{OH}-\Delta^{5} \mathrm{P}$ formation. The functional significance of $7 \alpha-\mathrm{OH}-\Delta^{5} \mathrm{P}$ in the control of locomotor activity is discussed in a companion paper (Haraguchi et al., 2011).

\section{CYTOCHROME P450 17 $\alpha$-HYDROXYLASE/C17,20-LYASE}

The microsomal enzyme cytochrome P450 17 $\alpha$-hydroxylase/C17, 20 -lyase $\left(\mathrm{P} 450_{\mathrm{C} 17} ; C Y P 17 A 1\right)$ possesses $17 \alpha$-hydroxylase activity and can thus convert $\Delta^{5} \mathrm{P}$ into 17-hydroxypregnenolone $(17 \mathrm{OH}$ $\Delta^{5} \mathrm{P}$ ) and $\mathrm{P}$ into 17-hydroxyprogesterone (17OH-P; Figure 1). $\mathrm{P}^{4} 0_{\mathrm{C} 17}$ also possesses 17,20-lyase activity and can thus convert $17 \mathrm{OH}-\Delta^{5} \mathrm{P}$ into DHEA and $17 \mathrm{OH}-\mathrm{P}$ into androstenedione ( $\Delta^{4}$; Miller, 2008; Figure 1). The search for the existence of $\mathrm{P}^{4} 50_{\mathrm{C} 17}$ in the brain of mammals has led to controversial results 
(Le Goascogne et al., 1991; Mellon and Deschepper, 1993; Compagnone et al., 1995b; Yamada et al., 1997; Hojo et al., 2004). In contrast, the occurrence of $\mathrm{P} 450_{\mathrm{C} 17}$ has been unequivocally demonstrated in the CNS of birds (Matsunaga et al., 2001) and amphibians (Do Rego et al., 2007). In R. esculenta, ${\mathrm{P} 450_{\mathrm{C} 17}}$ immunoreactivity is essentially located in neurons, notably in the diencephalon, but a few $\mathrm{P} 450_{\mathrm{C} 17}$-positive glial cells are also observed in the mesencephalon (Do Rego et al., 2007). Thus, a dense accumulation of $\mathrm{P}_{450} \mathrm{C} 17$-immunoreactive neurons is found in the anterior preoptic area, the ventral hypothalamic nuclei, the magnocellular nuclei, the posterior tuberculum, the habenular nuclei, and the nucleus of the periventricular organ. $\mathrm{P}^{4} 50_{\mathrm{C} 17}-$ positive neurons are also present in the olfactory bulb, the lateral amygdala and the medial pallium (Do Rego et al., 2007; Figure 3 ). Frog hypothalamic explants are capable of converting $\left[{ }^{3} \mathrm{H}\right] \Delta^{5} \mathrm{P}$ into $\mathrm{C}_{21} 17$-hydroxysteroids and $\mathrm{C}_{19}$ ketosteroids such as $17 \mathrm{OH}$ $\Delta^{5} \mathrm{P}, 17 \mathrm{OH}-\mathrm{P}, \mathrm{DHEA}$, and $\Delta^{4}$ (Do Rego et al., 2007) indicating that $C Y P 17$ expressed in the brain of amphibians actually possesses $17 \alpha$-hydroxylase and C17-20-lyase activities.

\section{$5 \alpha$-REDUCTASE}

3-Oxo-5 $\alpha$-steroid 4-dehydrogenase, more commonly termed $5 \alpha$ reductase ( $5 \alpha-\mathrm{R} ; S R D 5 A)$, is a microsomal enzyme that catalyzes the conversion of $\mathrm{P}$ to dihydroprogesterone (DHP) and the conversion of testosterone ( $\mathrm{T}$ ) to dihydrotestosterone (DHT; Russell and Wilson, 1994; Figure 1). In the brain, $5 \alpha-\mathrm{R}$ is involved in the biosynthetic pathway of $3 \alpha, 5 \alpha$-tetrahydroprogesterone (THP) also called allopregnanolone, a potent allosteric modulator of the $\mathrm{GABA}_{\mathrm{A}}$ receptor. $5 \alpha-\mathrm{R}$ is also responsible for the formation of the potent androgen DHT. The occurrence of $5 \alpha$-reductase in the brain of mammals, including humans, has long been documented (Saitoh et al., 1982; Pelletier et al., 1994; Melcangi et al., 1998; Torres and Ortega, 2003). In amphibians, the ontogeny of $5 \alpha$-reductase has been recently investigated in the brain of R. esculenta (Bruzzone et al., 2010). In the diencephalon, 5 $\alpha$ R-immunoreactive cell bodies are mainly found in the vascular plexuses, the epiphysis, the ventral part of the infundibular nucleus and the preoptic nucleus. In the mesencephalon, positive cells are located in the anterodorsal and anteroventral nuclei, the interpeduncular nucleus, the posterocentral and posterolateral nuclei, the torus semicircularis, and the central gray layer of the tectum. In the metencephalon, transient expression of $5 \alpha$-R occurs in the corpus cerebelli at stage X-XII when hindlimbs are lengthening. In the rhombencephalon, $5 \alpha$-R-containing cells are present in the medial

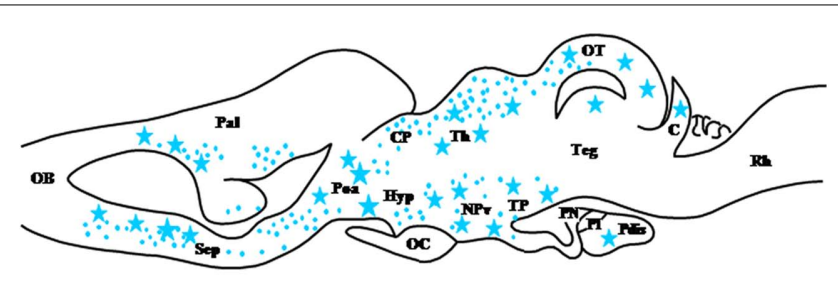

FIGURE 3 | Schematic parasagittal section depicting the distribution of cytochrome $\left.\mathbf{P 4 5 0}_{\mathrm{C} 17}\left(\mathbf{P}_{450}\right)_{\mathrm{c} 17}\right)$-immunoreactive cell bodies (stars) and fibers (dots) in the central nervous system of Rana esculenta (Do Rego et al., 2007). For other designations, see Figure 2. longitudinal fascicle and the superficial layer (Bruzzone et al., 2010; Figure 4). Interestingly, in the tadpole brain, $5 \alpha-\mathrm{R}$ immunoreactivity is found in both bipolar neurons and in glial cells (Vallarino et al., 2005). Incubation of tadpole brain explants with $\left[{ }^{3} \mathrm{H}\right] \Delta^{5} \mathrm{P}$ leads to the formation of several metabolites including $\mathrm{P}, 17 \mathrm{OH}-\mathrm{P}$, $\Delta^{4}$, and $5 \alpha$-DHT (Bruzzone et al., 2010) indicating that biologically active $3 \beta-\mathrm{HSD}, \mathrm{P} 450_{\mathrm{C} 17}$, and $5 \alpha-\mathrm{R}$ are already present in the CNS of amphibians during development.

\section{$3 \alpha$-HYDROXYSTEROID DEHYDROGENASE}

$3 \alpha$-Hydroxysteroid oxidoreductase, also called $3 \alpha$-hydroxysteroid dehydrogenase ( $3 \alpha-\mathrm{HSD} ; A K R 1 C)$ is a microsomal enzyme that catalyzes in a reversible manner the conversion of $5 \alpha-\mathrm{DHP}$ and $5 \alpha$-DHT into THP (allopregnanolone) and $3 \alpha$-androstanediol, respectively (Figure 1). $3 \alpha-\mathrm{HSD}$ is also involved in the reversible conversion of dihydrodeoxycorticosterone (DHDOC) into tetrahydrodeoxycorticosterone (THDOC; Penning et al., 2000; Figure 1). A single form of $3 \alpha$-HSD exists in rodents (Pawlowski et al., 1991) while four isoforms have been characterized in humans (Khanna et al., 1995). The distribution of $3 \alpha-\mathrm{HSD}$ mRNA and protein has been described in the brain of human (Griffin and Mellon, 1999; Steckelbroeck et al., 2001) and rodents (Khanna et al., 1995; Agís-Balboa et al., 2006), but has not yet been reported in amphibians. Using an antibody against human $3 \alpha$-HSD, we have recently observed the existence of $3 \alpha-H S D-$ immunoreactive neurons in the brain of R. esculenta. Positive cells are found in the olfactory bulb, the anterior commissure, the anterior preoptic area, the magnocellular preoptic nucleus, the ventral hypothalamic nucleus, the posterior thalamic nucleus, and the posterior tuberculum (unpublished observations). We have also seen that frog hypothalamic explants can synthesize THP from $\left[{ }^{3} \mathrm{H}\right] \Delta^{5} \mathrm{P}$ (unpublished observations), indicating that a bioactive form of $3 \alpha$-HSD is actually present in the brain of amphibians.

\section{7 $\beta$-HYDROXYSTEROID DEHYDROGENASE}

$17 \beta$-Hydroxysteroid dehydrogenase $(17 \beta-H S D ; H S D 17 B)$ is a bifunctional enzyme that catalyzes the interconversion of 17 ketosteroids and 17 $\beta$-hydroxysteroids (Payne and Hales, 2004). $17 \beta$-HSD thus plays a pivotal role in the biosynthesis and inactivation of sex steroid hormones (Figure 1). Twelve isoforms of $17 \beta$ HSD exhibiting different substrate specificity, tissue expression, and subcellular localization have been characterized in vertebrates (Luu-The, 2001; Luu-The et al., 2006). The occurrence of 17 $\beta$-HSD

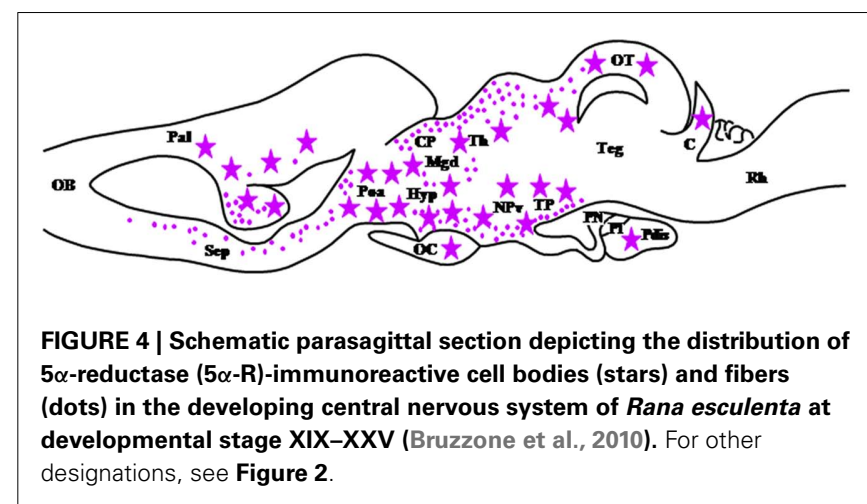


has been demonstrated in the brain of mammals (Pelletier et al., 1995; Hojo et al., 2004) and birds (Nomura et al., 1998; Matsunaga et al., 2002). In amphibians, immunohistochemical localization of $17 \beta$-HSD has been determined in the CNS of the frog Rana ridibunda using polyclonal antibodies against type I human placental 17 $\beta$-HSD (Dupont et al., 1991). In this species, 17 $\beta$-HSD immunoreactivity is found in a discrete population of glial cells. Positive gliocytes are located in the telencephalon, i.e., the periventricular zone of the medial pallium, and in the rostral region of the diencephalon (Mensah-Nyagan et al., 1996a,b; Figure 5). The presence of substantial amounts of $\mathrm{T}$ in the brain of both male and female frogs has been shown by gas chromatography-mass spectrometry and by HPLC analysis combined with radioimmunoassay (Mensah-Nyagan et al., 1996a,b). In male frogs, castration does not affect the concentration of T and $5 \alpha$-DHT in the telencephalon and hypothalamus (Mensah-Nyagan et al., 1996b). Finally, in vitro studies have demonstrated that frog telencephalon explants can convert $\left[{ }^{3} \mathrm{H}\right] \Delta^{5} \mathrm{P}$ into $\left[{ }^{3} \mathrm{H}\right] \mathrm{T}$ and $\left[{ }^{3} \mathrm{H}\right] 5 \alpha$-DHT (Mensah-Nyagan et al., 1996a,b). Altogether, these data provide strong evidence for the existence of a bioactive form of $17 \beta-H S D$ in the forebrain of amphibians and for the biosynthesis of sex steroids from $\Delta^{5} \mathrm{P}$ by glial cells of the telencephalon and diencephalon.

\section{CYTOCHROME P450 AROMATASE}

Cytochrome P450 aromatase (P450arom; CYP19AI) is a microsomal enzyme that catalyzes the transformation of androgens into estrogens (Simpson et al., 2002; Figure 1). It has long been established that aromatization of androgens is required for their regulatory effects in the CNS (MacLusky and Naftolin, 1981). Thus, P450arom plays a crucial role in the sexual differentiation of the brain and in the regulation of reproductive functions (GarciaSegura, 2008). The distribution of P450arom has been extensively investigated in the brain of mammals (Roselli et al., 1985; Balthazart et al., 1991; Abdelgadir et al., 1997) and birds (Balthazart et al., 1990; Evrard et al., 2004). The occurrence and localization of P450arom has also been described in the brain of teleost fish (Callard et al., 1978; Gelinas and Callard, 1997; Goto-Kazeto et al., 2004; Diotel et al., 2010). In amphibians, the presence of P450arom has been reported in the brain of Necturus maculosus (Callard et al., 1978) and R. esculenta (Guerriero et al., 2000). The expression of P450arom mRNA in the brain of Pleurodeles walt (Kuntz et al., 2004) and X. laevis (Urbatzka et al., 2007) has been investigated during development. In both species, the P450arom

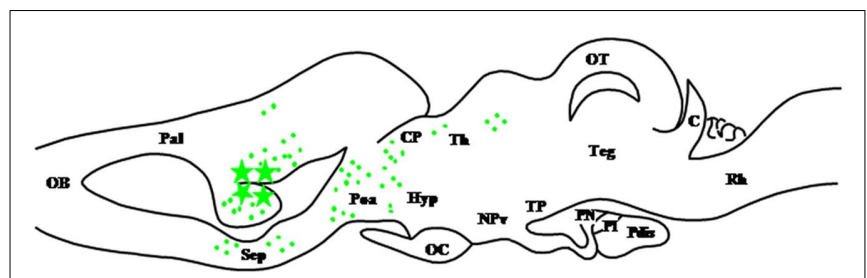

FIGURE 5 | Schematic parasagittal section depicting the distribution of $17 \beta$-hydroxysteroid dehydrogenase (17 $\beta$-HSD)-immunoreactive cell bodies (stars) and fibers (dots) in the central nervous system of Rana esculenta (Mensah-Nyagan et al., 1996a,b). For other designations, see Figure 2. gene is expressed from early developmental stages to metamorphosis without noticeable differences between males and females. However, the precise neuroanatomical distribution of P450arom mRNA or protein has not yet been determined in any amphibian species. Incubation of frog hypothalamic homogenates with $\left[{ }^{3} \mathrm{H}\right]$ DHEA induces the formation of estrone sulfate (Beaujean et al., 1999). Similarly, incubation of frog hypothalamic explants with $\left[{ }^{3} \mathrm{H}\right] \Delta^{5} \mathrm{P}$ yields to the biosynthesis of estradiol (MensahNyagan et al., 1996a,b). Taken together, these observations indicate that, in amphibians as in other vertebrate groups, an active form of aromatase is present in the brain.

\section{HYDROXYSTEROID SULFOTRANSFERASE}

Hydroxysteroid sulfotransferase (HST; SULT2) designates a family of cytosolic enzymes that transfer the sulfonate moiety from $3^{\prime}$ phosphoadenosine $5^{\prime}$-phosphosulfate (PAPS) on the 3-hydroxyl or the 21-hydroxyl group of steroid substrates (Strott, 2002; Figure 1). The observation that 3-hydroxysteroid sulfonates, such as pregnenolone sulfate ( $\left.\Delta^{5} \mathrm{PS}\right)$ and dehydroepiandrosterone sulfate (DHEAS), act as allosteric modulators of various receptors for neurotransmitters, notably $\mathrm{GABA}_{\mathrm{A}}$ receptors (Majewska, 1992; Le Foll et al., 1997) indicates that HST plays a critical role in the bioactivation of certain neurosteroids. Remarkably, while in mammals, immunohistochemical studies failed to detect HST in the brain (Sharp et al., 1993), in amphibians, the occurrence of HST immunoreactivity has been thoroughly investigated in $R$. ridibunda (Beaujean et al., 1999). Using an antiserum against rat liver HST, two populations of HST-immunoreactive neurons have been visualized in the dorsal part of the magnocellular preoptic nucleus and the anterior preoptic area (Figure 6). These neurons send projections in various regions of the telencephalon, diencephalon, and mesencephalon, notably in the medial amygdala, medial pallium, medial septum, nucleus accumbens, nucleus of the diagonal band of Broca, anterior thalamic nucleus, posterior thalamic nucleus, anterior preoptic area, basal optic nucleus, and nucleus reticularis isthmi (Beaujean et al., 1999). Incubation of frog telencephalon or hypothalamus homogenates with $\left[{ }^{3} \mathrm{H}\right] \Delta^{5} \mathrm{P}$ or $\left[{ }^{3} \mathrm{H}\right]$ DHEA as steroid precursors and $\left[{ }^{35} \mathrm{~S}\right] \mathrm{PAPS}$ as a sulfate donor yields the formation of several ${ }^{3} \mathrm{H},{ }^{35} \mathrm{~S}$-labeled steroids including $\Delta^{5} \mathrm{PS}$, DHEAS, and testostosterone sulfate (TS; Beaujean et al., 1999). De novo synthesis of 3-hydroxysteroid sulfate is blocked by the sulfotransferase inhibitor 2,4-dichloro-6-nitrophenol (Beaujean et al., 1999). These data demonstrate that the brain of amphibians

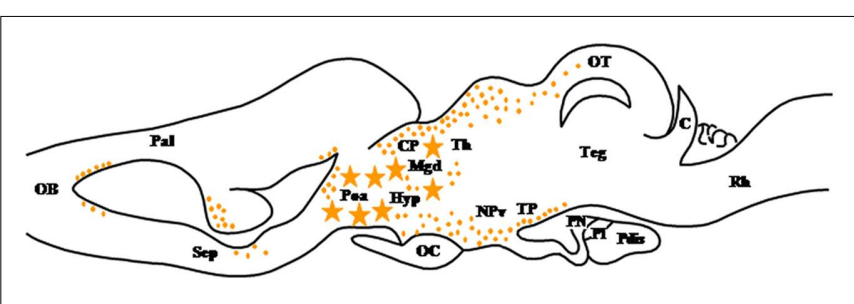

FIGURE 6 | Schematic parasagittal section depicting the distribution of hydroxysteroid sulfotransferase (HST)-immunoreactive cell bodies (stars) and fibers (dots) in the central nervous system of Rana esculenta (Beaujean et al., 1999). For other designations, see Figure 2. 
expresses HST and has the ability to synthesize the highly potent neurosteroids $\Delta^{5} \mathrm{PS}$ and DHEAS.

\section{CONCLUDING REMARKS}

Amphibians have been widely used as animal models to investigate neurosteroid biosynthesis in the brain. The neuroanatomical distribution of most key steroidogenic enzymes has now been determined in the brain of anurans and/or urodeles. For some of these enzymes, e.g., 3 $\beta$-HSD and HST, the immunohistochemical localization in the CNS has been first reported in amphibians. Biochemical studies have demonstrated that these enzymes are able to convert radiolabeled steroid precursors such as $\left[{ }^{3} \mathrm{H}\right] \Delta^{5} \mathrm{P}$ or $\left[{ }^{3} \mathrm{H}\right]$ DHEA into biologically active steroids. The occurrence of high concentrations of steroids in brain tissue confirms that amphibians have the ability to synthesize neurosteroids which are, at least in part, produced independently of steroidogenic glands. The fact that amphibians and mammals, which diverged approximately 350 million years ago, have in common the ability

\section{REFERENCES}

Abdelgadir, S. E., Roselli, C. E., Choate, J. V., and Resko, J. A. (1997). Distribution of aromatase cytochrome P450 messenger ribonucleic acid in adult rhesus monkey brains. Biol. Reprod. 57, 772-777.

Agís-Balboa, R. C., Pinna, G., Zhubi, A., Maloku, E., Veldic, M., Costa, E., and Guidotti, A. (2006). Characterization of brain neurons that express enzymes mediating neurosteroid biosynthesis. Proc. Natl. Acad. Sci. U.S.A. 103, 14602-14607.

Arukwe, A. (2008). Steroidogenic acute regulatory (StAR) protein and cholesterol side-chain cleavage (P450scc)-regulated steroidogenesis as an organ-specific molecular and cellular target for endocrine disrupting chemicals in fish. Cell Biol. Toxicol. 24, 527-540.

Balthazart, J., Foidart, A., Surlemont, C., and Harada, N. (1991). Distribution of aromatase-immunoreactive cells in the mouse forebrain. Cell Tissue Res. 263, 71-79.

Balthazart, J., Foidart, A., Surlemont, C., Vockel, A., and Harada, N. (1990). Distribution of aromatase in the brain of the Japanese quail, ring dove, and zebra finch: an immunocytochemical study. J. Comp. Neurol. 301, 276-288.

Beaujean, D., Mensah-Nyagan, A. G., Do Rego, J. L., Luu-The, V., Pelletier, G., and Vaudry, H. (1999). Immunocytochemical localization and biological activity of hydroxysteroid sulfotransferase in the frog brain. J. Neurochem. 72, 848-857.

Belelli, D., Herd, M. B., Mitchell, E. A., Peden, D. R., Vardy, A. W., Gentet, L., and Lambert, J. J. (2006). Neuroactive steroids and inhibitory neurotransmission: mechanisms of action and physiological relevance. Neuroscience 138, 821-829.

Belelli, D., and Lambert, J. J. (2005). Neurosteroids: endogenous regulators of the GABAA receptor. Nat. Rev. Neurosci. 6, 565-575.

Bruzzone, F., Do Rego, J. L., Ciarlo, M., Griffero, F., Luu-The, V., Pelletier, G., Vallarino, M., and Vaudry, H. (2010). Immunohistochemical localization and biological activity of $3 \beta$-hydroxysteroid dehydrogenase and $5 \alpha$-reductase in the brain of the frog, Rana esculenta, during development. J. Chem. Neuroanat. 39, 35-50.

Callard, G. V., Petro, Z., and Ryan, K. J. (1978). Phylogenetic distribution of aromatase and other androgenconverting enzymes in the central nervous system. Endocrinology 103, 2283-2290.

Cheney, D. L., Uzunov, D., Costa, E., and Guidotti, A. (1995). Gas chromatographic-mass fragmentographic quantitation of $3 \alpha$-hydroxy- $5 \alpha$-pregnan-20-one (allopregnanolone) and its precursors in blood and brain of adrenalectomized and castrated rats. J. Neurosci. 15, 4641-4650.

Compagnone, N. A., Bulfone, A., Rubenstein, J. L. R., and Mellon, S. (1995a). Expression of the steroidogenic enzyme cytochrome $\mathrm{P} 450$ scc in the central and peripheral nervous systems during rodent embryogenesis. Endocrinology 136, 2689-2696.

Compagnone, N. A., Bulfone, A., Rubenstein, J. L., and Mellon, S. H. (1995b). Steroidogenic enzyme P450c17 is expressed in the embryonic central nervous system. Endocrinology 136, 5212-5223.

to synthesize de novo biologically active steroids in their brain supports the view that neurosteroids are playing vital functions throughout the animal kingdom.

\section{ACKNOWLEDGMENTS}

This work was supported by grants from the Institut National de la Santé et de la Recherche Médical (INSERM U413/U982), the Ministère des Affaires Etrangères (France-Québec exchange program to Georges Pelletier and Hubert Vaudry), a FranceQuébec exchange program (INSERM-Fonds de la Recherche en Santé du Québec, FRSQ, to Georges Pelletier and Hubert Vaudry), a France-Japan exchange program (INSERM-Japan Society for the Promotion of Science, JSPS, to Kazuyoshi Tsutsui, Hubert Vaudry, and Jean-Luc Do Rego), the Plate-Forme Régionale de Recherche en Imagerie Cellulaire de Haute-Normandie (PRIMACEN), and the Région Haute-Normandie. Hubert Vaudry is Associated Researcher at the Research Center in Molecular Endocrinology, Oncology, and Genetics, Laval University, Québec.

Compagnone, N. A., and Mellon, S. H. (2000). Neurosteroids: biosynthesis and function of these novel neuromodulators. Front. Neuroendocrinol. 21, 1-56.

Corpéchot, C., Robel, P., Axelson, M., Sjövall, J., and Baulieu, E. E. (1981). Characterization and measurement of dehydroepiandrosterone sulfate in rat brain. Proc. Natl. Acad. Sci. U.S.A. 78, 4704-4707.

Corpéchot, C., Synguelakis, M., Talha, S., Axelson, M., Sjövall, J., Vihko, R., Baulieu, E. E., and Robel, P. (1983). Pregnenolone and its sulfate ester in the rat brain. Brain Res. 270, 119-125.

Diotel, N., Le Page, Y., Mouriec, K., Tong, S. K., Pellegrini, E., Vaillant, C., Anglade, I., Brion, F., Pakdel, F., Chung, B. C., and Kah, O. (2010). Aromatase in the brain of teleost fish: expression, regulation and putative functions. Front. Neuroendocrinol. 31, 172-192.

Do Rego, J. L., Mensah-Nyagan, A. G., Feuilloley, M., Ferrara, P., Pelletier, G., and Vaudry, H. (1998). The endozepine triakontatetraneuropeptide diazepam-binding inhibitor [17-50] stimulates neurosteroid biosynthesis in the frog hypothalamus. Neuroscience 83, 555-570.

Do Rego, J. L., Seong, J. Y., Burel, D., Leprince, J., Luu-The, V., Tsutsui, K., Tonon, M. C., Pelletier, G., and Vaudry, H. (2009). Neurosteroid biosynthesis: enzymatic pathways and neuroendocrine regulation by neurotransmitters and neuropeptides. Front. Neuroendocrinol. 30, 259-301.

Do Rego, J. L., Tremblay, Y., LuuThe, V., Repetto, E., Castel, H.,
Vallarino, M., Bélanger, A., Pelletier, G., and Vaudry, H. (2007) Immunohistochemical localization and biological activity of the steroidogenic enzyme cytochrome P450 17 $\alpha$-hydroxylase/C17, 20lyase (P450C17) in the frog brain and pituitary. J. Neurochem. 100, 251-268.

Dupont, E., Labrie, F., Luu-The, V., and Pelletier, G. (1991). Localization of $17 \beta$-hydroxysteroid dehydrogenase throughout gestation in human placenta. J. Histochem. Cytochem. 39, 1403-1407.

Dupont, E., Simard, J., Luu-The, V., Labrie, F., and Pelletier, G. (1994). Localization of $3 \beta$-hydroxysteroid dehydrogenase in rat brain as studied by in situ hybridization. Mol. Cell. Neurosci. 5, 119-123.

Evrard, H. C., Harada, N., and Balthazart, J. (2004). Immunocytochemical localization of aromatase in sensory and integrating nuclei of the hindbrain in Japanese quail (Coturnix japonica). J. Comp. Neurol. 473, 194-212.

Farkash, Y., Timberg, R., and Orly, J. (1986). Preparation of antiserum to rat cytochrome P450cholesterol side chain cleavage, and its use for ultrastructural localization of the immunoreactive enzyme by protein A-gold technique. Endocrinology 118, 1353-1365.

Furukawa, A., Miyatake, A., Ohnishi, T., and Ichikawa, Y. (1998). Steroidogenic acute regulatory protein (StAR) transcripts constitutively expressed in the adult rat central nervous system: colocalization of StAR, cytochrome P450scc (CYP XIA1), and 3 $\beta$-hydroxysteroid dehydrogenase in the rat brain. $J$. Neurochem. 71, 2231-2238. 
Garcia-Segura, L. M. (2008). Aromatase in the brain: not just for reproduction anymore. J. Neuroendocrinol. 20, 705-712.

Gelinas, D., and Callard, G. V. (1997). Immunolocalization of aromataseand androgen receptor-positive neurons in the goldfish brain. Gen. Comp. Endocrinol. 106, 155-168.

Gilardi, F., Mitro, N., Godio, C., Scotti, E., Caruso, D., Crestani, M., and De Fabiani, E. (2007). The pharmacological exploitation of cholesterol $7 \alpha$-hydroxylase, the key enzyme in bile acid synthesis: from binding resins to chromatin remodelling to reduce plasma cholesterol. Pharmacol. Ther. 116, 449-472.

Goto-Kazeto, R., Kight, K. E., Zohar, Y., Place, A. R., and Trant, J. M. (2004). Localization and expression of aromatase mRNA in adult zebrafish. Gen. Comp. Endocrinol. 139, 72-84.

Griffin, L. D., and Mellon, S. H. (1999). Selective serotonin reuptake inhibitors directly alter activity of neurosteroidogenic enzymes. Proc. Natl. Acad. Sci. U.S.A. 96, 13512-13517.

Guennoun, R., Fiddes, R. J., Gouézou, M., Lombès, M., and Baulieu, E. E. (1995). A key enzyme in the biosynthesis of neurosteroids, $3 \beta$-hydroxysteroid dehydrogenase/ $\Delta 5$ - $\Delta 4$-isomerase

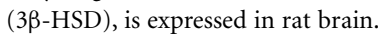
Brain Res. Mol. Brain Res. 30, 287-300.

Guerriero, G., Roselli, C. E., Paolucci, M., Botte, V., and Ciarcia, G. (2000). Estrogen receptors and aromatase activity in the hypothalamus of the female frog, Rana esculenta. Fluctuations throughout the reproductive cycle. Brain Res. 880, 92-101.

Guo, I. C., Shih, M. C., Lan, H. C., Hsu, N. C., Hu, M. C., and Chung, B. C. (2007). Transcriptional regulation of human CYP11A1 in gonads and adrenals. J. Biomed. Sci. 14, 509-515.

Haraguchi, S., Koyama, T., Do Rego, J. L., and Tsutsui, K. (2009). Seasonal changes in the synthesis of $7 \alpha$-hydroxypregnenolone stimulating locomotor activity in newts. Ann. N. Y. Acad. Sci. 1163, 410-413.

Haraguchi, S., Koyama, T., Hasunuma, I., Vaudry, H., and Tsutsui, K. (2010). Prolactin increases the synthesis of $7 \alpha$-hydroxypregnenolone, a key factor for induction of locomotor activity, in breeding male newts. Endocrinology 151, 2211-2222.

Haraguchi, S., Matsunaga, M., Vaudry, H., and Tsutsui, K. (2011). Review: mode of action and functional significance of
7 $\alpha$-hydroxypregnenolone stimulating locomotor activity. Front. Endocrinol. 2:23. doi:10.3389/fendo.2011.00023

Herd, M. B., Belelli, D., and Lambert, J. J. (2007). Neurosteroid modulation of synaptic and extrasynaptic GABAA receptors. Pharmacol. Ther. $116,20-34$.

Hojo, Y., Hattori, T. A., Enami, T., Furukawa, A., Suzuki, K., Ishii, H. T., Mukai, H., Morrison, J. H., Janssen, W. G. M., Kominami, S., Harada, N., and Kimoto, T. (2004). Adult male rat hippocampus synthesizes estradiol from pregnenolone by cytochromes $\mathrm{P} 45017 \alpha$ and $\mathrm{P} 450$ aromatase localized in neurons. Proc. Natl. Acad. Sci. U.S.A. 101, 865-870.

Inai, Y., Nagai, K., Ukena, K., Oishi, T., and Tsutsui, K. (2003). Seasonal changes in neurosteroid concentrations in the amphibian brain and environmental factors regulating their changes. Brain Res. 959, 214-225.

Inoue, T., Akahira, J., Suzuki, T., Darnel, A. D., Kaneko, C., Takahashi, K., Hatori, M., Shirane, R., Kumabe, T., Kurokawa, Y., Satomi, S., and Sasano, H. (2002). Progesterone production and actions in the human central nervous system and neurogenic tumors. J. Clin. Endocrinol. Metab. 87, 5325-5331.

Karishma, K. K., and Herbert, J. (2002). Dehydroepiandrosterone (DHEA) stimulates neurogenesis in the hippocampus of the rat, promotes survival of newly formed neurons and prevents corticosteroneinduced suppression. Eur. J. Neurosci. 16, 445-453.

Khanna, M., Qin, K. N., Wang, R. W., and Cheng, K. C. (1995). Substrate specificity, gene structure, and tissue-specific distribution of multiple human $3 \alpha$-hydroxysteroid dehydrogenases. J. Biol. Chem. 270, 20162-20168.

Kimoto, T., Tsurugizawa, T., Ohta, Y., Makino, J., Tamura, H., Hojo, Y., Takata, N., and Kawato, S. (2001). Neurosteroid synthesis by cytochrome p450-containing systems localized in the rat brain hippocampal neurons: N-methylD-aspartate and calcium-dependent synthesis. Endocrinology 142, 3578-3589.

Koyama, T., Haraguchi, S., Vaudry, H., and Tsutsui, K. (2009). Diurnal changes in the synthesis of $7 \alpha$-hydroxypregnenolone stimulating locomotor activity in newts. Ann. N. Y. Acad. Sci. 1163, 444-447.

Kuntz, S., Chesnel, A., Flament, S., and Chardard, D. (2004). Cerebral and gonadal aromatase expressions are differently affected during sex differentiation of Pleurodeles waltl. J. Mol. Endocrinol. 33, 717-727.

Kusakabe, M., Zuccarelli, M. D., Nakamura, I., and Young, G. (2009). Steroidogenic acute regulatory protein in white sturgeon (Acipenser transmontanus): cDNA cloning, sites of expression and transcript abundance in corticosteroidogenic tissue after an acute stressor. Gen. Comp. Endocrinol. 162, 233-240.

Lavoie, H. A., and King, S. R. (2009). Transcriptional regulation of steroidogenic genes: STARD1, CYP11A1 and HSD3B. Exp. Biol. Med. (Maywood) 234, 880-907.

Lazaridis, I., Charalampopoulos, I., Alexaki, V. I., Avlonitis, N., Pediaditakis, I., Efstathopoulos, P., Calogeropoulou, T., Castanas, E., and Gravanis, A. (2011). Neurosteroid dehydroepiandrosterone interacts with nerve growth factor (NGF) receptors, preventing neuronal apoptosis. PLoS Biol. 9, e1001051. doi:10.1371/journal.pbio.1001051

Le Foll, F., Louiset, E., Castel, H., Vaudry, H., and Cazin, L. (1997). Electrophysiological effects of various neuroactive steroids on the GABAA receptor in pituitary melanotrope cells. Eur. J. Pharmacol. 331, 303-311.

Le Goascogne, C., Gouézou, M., Robel, P., Defaye, G., Chambaz, E., Waterman, M. R., and Baulieu, E. E. (1989). The cholesterol side-chain cleavage complex in human brain white matter. J. Neuroendocrinol. 1 , 153-156.

Le Goascogne, C., Robel, P., Gouézou, M., Sananès, N., Baulieu, E. E. and Waterman, M. (1987). Neurosteroids: cytochrome $\mathrm{P} 450 \mathrm{scc}$ in rat brain. Science 237, 1212-1215.

Le Goascogne, C., Sananès, N., Gouézou, M., Takemori, S., Kominami, S., Baulieu, E. E., and Robel, P. (1991). Immunoreactive cytochrome $\mathrm{P}-450(17 \alpha)$ in rat and guinea pig gonads, adrenal glands and brain. J. Reprod. Fertil. 93, 609-622.

Lea, R. W., Clark, J. A., and Tsutsui, K. (2001). Changes in central steroid receptor expression, steroid synthesis, and dopaminergic activity related to the reproductive cycle of the ring dove. Microsc. Res. Tech. 55, 12-26.

London, S. E., Monks, D. A., Wade, J., and Schlinger, B. A. (2006). Widespread capacity for steroid synthesis in the avian brain and song system. Endocrinology 147, 5975-5987.
Luu-The, V. (2001). Analysis and characteristics of multiple types of human 17 $\beta$-hydroxysteroid dehydrogenase. J. Steroid Biochem. Mol. Biol. 76, 143-151.

Luu-The, V., Tremblay, P., and Labrie, F. (2006). Characterization of type 12 17/-hydroxysteroid dehydrogenase, an isoform of type 3 $17 \beta$-hydroxysteroid dehydrogenase responsible for estradiol formation in women. Mol. Endocrinol. 20, 437-443.

Lyssimachou, A., and Arukwe, A. (2007). Alteration of brain and interrenal StAR protein, P450scc, and Cyp $11 \beta$ mRNA levels in Atlantic salmon after nominal waterborne exposure to the synthetic pharmaceutical estrogen ethynyl estradiol. J. Toxicol. Environ. Health A 70 , 606-613.

MacLusky, N. J., and Naftolin, F. (1981). Sexual differentiation of the central nervous system. Science 211, 1294-1302.

Majewska, M. D. (1992). Neurosteroids: endogenous bimodal modulators of the GABAA receptor. Mechanism of action and physiological significance. Prog. Neurobiol. 38, 379-395.

Matsunaga, M., Ukena, K., Baulieu, E. E., and Tsutsui, K. (2004). $7 \alpha-$ hydroxypregnenolone acts as a neuronal activator to stimulate locomotor activity of breeding newts by means of the dopaminergic system. Proc. Natl. Acad. Sci. U.S.A. 101, 17282-17287.

Matsunaga, M., Ukena, K., and Tsutsui, K. (2001). Expression and localization of cytochrome P450 17 $\alpha$ hydroxylase/c17, 20-lyase in the avian brain. Brain Res. 899, 112-122.

Matsunaga, M., Ukena, K., and Tsutsui, K. (2002). Androgen biosynthesis in the quail brain. Brain Res. 948 , 180-185.

McEwen, B. S. (1992). Steroid hormones: effect on brain development and function. Horm. Res. 37, 1-10.

Melcangi, R. C., Poletti, A., Cavarretta, I., Celotti, F., Colciago, A., Magnaghi, V., Motta, M., Negri-Cesi, P., and Martini, L. (1998). The $5 \alpha-$ reductase in the central nervous system: expression and modes of control. J. Steroid Biochem. Mol. Biol. 65 295-299.

Mellon, S., and Vaudry, H. (2001). Biosynthesis of neurosteroids and regulation of their synthesis. Int. Rev. Neurobiol. 46, 33-78.

Mellon, S. H., and Deschepper, C. F. (1993). Neurosteroid biosynthesis: genes for adrenal steroidogenic enzymes are expressed in the brain. Brain Res. 629, 283-292. 
Mensah-Nyagan, A. G., Do Rego, J. L., Beaujean, D., Luu-The, V., Pelletier, G., and Vaudry, H. (1999). Neurosteroids: expression of steroidogenic enzymes and regulation of steroid biosynthesis in the central nervous system. Pharmacol. Rev. 51, 63-81.

Mensah-Nyagan, A. G., Feuilloley, M., Do Rego, J. L., Marcual, A., Lange, C., Tonon, M. C., Pelletier, G., and Vaudry, H. (1996a). Localization of $17 \beta$-hydroxysteroid dehydrogenase and characterization of testosterone in the brain of the male frog. Proc. Natl. Acad. Sci. U.S.A. 93, 1423-1428.

Mensah-Nyagan, A. G., Do Rego, J. L., Feuilloley, M., Marcual,A., Lange, C., Pelletier, G., and Vaudry, H. (1996b). In vivo and in vitro evidence for the biosynthesis of testosterone in the telencephalon of the female frog. J. Neurochem. 67, 413-422.

Mensah-Nyagan, A. G., Feuilloley, M., Dupont, E., Do Rego, J. L., Leboulenger, F., Pelletier, G., and Vaudry, H. (1994). Immunocytochemical localization and biological activity of $3 \beta$-hydroxysteroid dehydrogenase in the central nervous system of the frog. J. Neurosci. 14, 7306-7318.

Miller, W. L. (2008). Steroidogenic enzymes. Endocr. Dev. 13, 1-18.

Neary, T. J., and Northcutt, R. G. (1983). Nuclear organization of the bullfrog diencephalon. J. Comp. Neurol. 213, 262-278.

Nomura, O., Nishimori, K., Nakabayashi, O., Yasue, H., and Mizuno, S. (1998). Determination by modified RT-PCR of transcript amounts from genes involved in sex-steroid synthesis in chicken organs including brain. J. Steroid Biochem. Mol. Biol. 67, 143-148.

Norlin, M., and Wikvall, K. (2007). Enzymes in the conversion of cholesterol into bile acids. Curr. Mol. Med. 7, 199-218.

Northcutt, R. G., and Kicliter, E. (1980). "Organization of the amphibian telencephalon," in Comparative Neurology of the Telencephalon, ed. S. O. E. Ebbeson (New York: Plenum Press), 203-255.

Nunez, B. S., Piermarini, P. M., Evans, A. N., and Applebaum, S. L. (2005). Cloning and characterization of cDNAs encoding steroidogenic acute regulatory protein from freshwater stingrays (Potamotrygon spp.). J. Mol. Endocrinol. 35, 557-569.

Oke, B. O., Suarez-Quian, C. A., Riond, J., Ferrara, P., and Papadopoulos, V. (1992). Cell surface localization of the peripheral-type benzodiazepine receptor (PBR) in adrenal cortex. Mol. Cell. Endocrinol. 87, R1-R6.
Papadopoulos, V., Amri, H., Boujrad, N., Cascio, C., Culty, M., Garnier, M., Hardwick, M., Li, H., Vidic, B., Brown, A. S., Reversa, J. L., Bernassau, J. M., and Drieu, K. (1997). Peripheral benzodiazepine receptor in cholesterol transport and steroidogenesis. Steroids 62, 21-28.

Papadopoulos, V., Baraldi, M., Guilarte, T. R., Knudsen, T. B., Lacapère, J. J., Lindemann, P., Norenberg, M. D., Nutt, D., Weizman, A., Zhang, M. R., and Gavish, M. (2006). Translocator protein $(18 \mathrm{kDa})$ : new nomenclature for the peripheraltype benzodiazepine receptor based on its structure and molecular function. Trends Pharmacol. Sci. 27, 402-409.

Pawlowski, J. E., Huizinga, M., and Penning, T. M. (1991). Cloning and sequencing of the cDNA for rat liver $3 \alpha$-hydroxysteroid/dihydrodiol dehydrogenase. J. Biol. Chem. 266, 8820-8825.

Payne, A. H., and Hales, D. B. (2004). Overview of steroidogenic enzymes in the pathway from cholesterol to active steroid hormones. Endocr. Rev. 2004, 25, 947-970.

Pelletier, G., Luu-The, V., and Labrie, F. (1994). Immunocytochemical localization of $5 \alpha$-reductase in rat brain. Mol. Cell. Neurosci. 5, 394-399.

Pelletier, G., Luu-The, V., and Labrie, F. (1995). Immunocytochemical localization of type I $17 \beta$-hydroxysteroid dehydrogenase in the rat brain. Brain Res. 704, 233-239.

Penning, T. M., Burczynski, M. E., Jez, J. M., Hung, C. F., Lin, H. K., Ma, H., Moore, M., Palackal, N., and Ratnam, K. (2000). Human $3 \alpha-$ hydroxysteroid dehydrogenase isoforms (AKR1C1-AKR1C4) of the aldo-keto reductase superfamily: functional plasticity and tissue distribution reveals roles in the inactivation and formation of male and female sex hormones. Biochem. J. 351, 67-77.

Robel, P., and Baulieu, E. E. (1985). Neurosteroids, $\quad 3 \beta$-hydroxy- $\Delta 5$ derivatives in the rodent brain. Neurochem. Int. 7, 953-958.

Roselli, C. E., Horton, L. E., and Resko, J. A. (1985). Distribution and regulation of aromatase activity in the rat hypothalamus and limbic system. Endocrinology 117, 2471-2477.

Rupprecht, R., Rammes, G., Eser, D., Baghai, T. C., Schüle, C., Nothdurfter, C., Troxler, T., Gentsch, C., Kalkman, H. O., Chaperon, F., Uzunov, V., McAllister, K. H., Bertaina-Anglade, V., La Rochelle, C. D., Tuerck, D., Floesser, A.,
Kiese, B., Schumacher, M., Landgraf, R., Holsboer, F., and Kucher, K. (2009). Translocator protein (18 $\mathrm{kD})$ as target for anxiolytics without benzodiazepine-like side effects. Science 325, 490-493.

Russell, D. W., and Wilson, J. D. (1994). Steroid $5 \alpha$-reductase: two genes/two enzymes. Annu. Rev. Biochem. 63, 25-61.

Saitoh, H., Hirato, K., Yanaihara, T., and Nakayama, T. (1982). A study of $5 \alpha$-reductase in human fetal brain. Endocrinol. Jpn. 29, 461-467.

Sakamoto, H., Ukena, K., and Tsutsui, K. (2001). Effects of progesterone synthesized de novo in the developing Purkinje cell on its dendritic growth and synaptogenesis. J. Neurosci. 21, 6221-6232.

Sanne, J. L., and Krueger, K. E. (1995). Expression of cytochrome $\mathrm{P} 450$ side-chain cleavage enzyme and $3 \beta$ hydroxysteroid dehydrogenase in the rat central nervous system: a study by polymerase chain reaction and in situ hybridisation. J. Neurochem. 65, 528-536.

Sharp, S., Barker, E. V., Coughtrie, M. W. H., Lowenstein, P. R., and Hume, R. (1993). Immunochemical characterization of a dehydroepiandrosterone sulfotransferase in rats and humans. Eur. J. Biochem. 211, 539-548.

Simard, J., Ricketts, M. L., Gingras, S., Soucy, P., Feltus, F. A., and Melner, M. H. (2005). Molecular biology of the $3 \beta$ hydroxysteroid dehydrogenase/ $\Delta 5$ $\Delta 4$ isomerase gene family. Endocr. Rev. 26, 525-582.

Simpson, E. R., Clyne, C., Rubin, G. Boon, W. C., Robertson, K., Britt, K., Speed, C., and Jones, M. (2002). Aromatase: a brief overview. Annu. Rev. Physiol. 64, 93-127.

Stapleton, G., Steel, M., Richardson, M., Mason, J. O., Rose, K. A., Morris, R. G., and Lathe, R. (1995). A novel cytochrome P450 expressed primarily in brain. J. Biol. Chem. 270, 29739-29745.

Steckelbroeck, S., Watzka, M., Reichelt, R., Hans, V. H., Stoffel-Wagner, B., Heidrich, D. D., Schramm, J., Bidlingmaier, F., and Klingmüller, D. (2001). Characterization of the $5 \alpha$ reductase- $3 \alpha$-hydroxysteroid dehydrogenase complex in the human brain. J. Clin. Endocrinol. Metab. 86, 1324-1331.

Stocco, D. M. (2001). StAR protein and the regulation of steroid hormone biosynthesis. Annu. Rev. Physiol. 63, 193-213.

Strott, C. A. (2002). Sulfonation and molecular action. Endocr. Rev. 23, 703-732.

Takase, M., Haraguchi, S., Hasunuma, I., Kikuyama, S., and Tsutsui, K. (2011).
Expression of cytochrome P450 side-chain cleavage enzyme mRNA in the brain of the red-bellied newt Cynops pyrrhogaster. Gen. Comp. Endocrinol. 170, 468-474.

Takase, M., Ukena, K., Yamazaki, T., Kominami, S., and Tsutsui, K. (1999). Pregnenolone, pregnenolone sulfate, and cytochrome P450 side-chain cleavage enzyme in the amphibian brain and their seasonal changes. Endocrinology 140, 1936-1944.

Torres, J. M., and Ortega, E. (2003). Differential regulation of steroid $5 \alpha$ reductase isozymes expression by androgens in the adult rat brain. FASEB J. 17, 1428-1433.

Tsutsui, K., Haraguchi, S., Matsunaga, M., Koyama, T., Do Rego, J. L., and Vaudry, H. (2010a). Identification of $7 \alpha$-hydroxypregnenolone, a novel bioactive amphibian neurosteroid stimulating locomotor activity, and its physiological roles in the regulation of locomotion. Gen. Comp. Endocrinol. 168, 275-279.

Tsutsui, K., Haraguchi, S., Matsunaga, M., Inoue, K., and Vaudry, $\mathrm{H}$. (2010b). 7 $\alpha$-hydroxypregnenolone, a new key regulator of locomotor activity of vertebrates: identification, mode of action and functional significance. Front. Endocrinol. 1:9. doi:10.3389/fendo.2010.00009

Tsutsui, K., Inoue, K., Miyabara, H., Suzuki, S., Ogura, Y., and Haraguchi, S. (2008). $7 \alpha$-hydroxypregnenolone mediates melatonin action underlying diurnal locomotor rhythms. J. Neurosci. 28, 2158-2167.

Tsutsui, K., Ukena, K., Takase, M., Kohchi, C., and Lea, R. W. (1999). Neurosteroid biosynthesis in vertebrate brains. Comp. Biochem. Physiol. CPharmacol. Toxicol. Endocrinol. 124, 121-129.

Tsutsui, K., and Yamazaki, T. (1995). Avian neurosteroids I. Pregnenolone biosynthesis in the quail brain. Brain Res. 678, 1-9.

Ukena, K., Honda, Y., Lea, R. W., and Tsutsui, K. (2001). Developmental changes in progesterone biosynthesis and metabolism in the quail brain. Brain Res. 898, 190-194.

Ukena, K., Usui, M., Kohchi, C., and Tsutsui, K. (1998). Cytochrome P450 side-chain cleavage enzyme in the cerebellar Purkinje neuron and its neonatal change in rats. Endocrinology 139, 137-147.

Ukena, K., Usui, M., Kohchi, C., and Tsutsui, K. (1999a). Expression and activity of $3 \beta$-hydroxysteroid dehydrogenase/ $\Delta 5-\Delta 4$ isomerase in the rat Purkinje neuron during neonatal life. Endocrinology 140, 805-813. 
Ukena, K., Honda, Y., Inai, Y., Kohchi, C., Lea, R. W., and Tsutsui, K. (1999b). Expression and activity of $3 \beta$ hydroxysteroid dehydrogenase $/ \Delta 5$ $\Delta 4$ isomerase in different regions of the avian brain. Brain Res. 818 , 536-542.

Urbatzka, R., Lutz, I., and Kloas, W. (2007). Aromatase, steroid-5 $\alpha$-reductase type 1 and type 2 mRNA expression in gonads and in brain of Xenopus laevis during ontogeny. Gen. Comp. Endocrinol. 153, 280-288.

Usui, M., Yamazaki, T., Kominami, S., and Tsutsui, K. (1995). Avian neurosteroids II. Localization of a cytochrome P450scc-like substance in the quail brain. Brain Res. 678, 10-20.

Vallarino, M., Mathieu, M., do-Rego, J. L., Bruzzone, F., Chartrel, N. Luu-The, V., Pelletier, G., and Vaudry, H. (2005). Ontogeny of $3 \beta$-hydroxysteroid dehydrogenase and $5 \alpha$-reductase in the frog brain. Ann. N. Y. Acad. Sci. 1040, 490-493.

Wang, J. M., Johnston, P. B., Ball, B. G., and Brinton, R. D. (2005). The neurosteroid allopregnanolone promotes proliferation of rodent and human neural progenitor cells and regulates cell-cycle gene and protein expression. J. Neurosci. 25, 4706-4718.
Yamada, H., Kominami, S., Takemori, S., Kitawaki, J., and Kataoka, Y. (1997). Immunohistochemical localization of cytochrome P450 enzymes in the rat brain, considering the steroidsynthesis in the neurons. Acta Histochem. Cytochem. 30, 609-616.

Conflict of Interest Statement: The authors declare that the research was conducted in the absence of any commercial or financial relationships that could be construed as a potential conflict of interest.

Received: 13 September 2011; paper pending published: 19 October 2011; accepted: 08 November 2011; published online: 30 November 2011.
Citation: Vaudry H, Do Rego J-L, Burel D, Luu-The V, Pelletier G Vaudry D and Tsutsui K (2011) Neurosteroid biosynthesis in the brain of amphibians. Front. Endocrin. 2:79. doi: 10.3389/fendo.2011.00079

This article was submitted to Frontiers in Neuroendocrine Science, a specialty of Frontiers in Endocrinology.

Copyright (C) 2011 Vaudry, Do Rego, Burel, Luu-The, Pelletier, Vaudry and Tsutsui. This is an open-access article distributed under the terms of the Creative Commons Attribution Non Commercial License, which permits non-commercial use, distribution, and reproduction in other forums, provided the original authors and source are credited. 